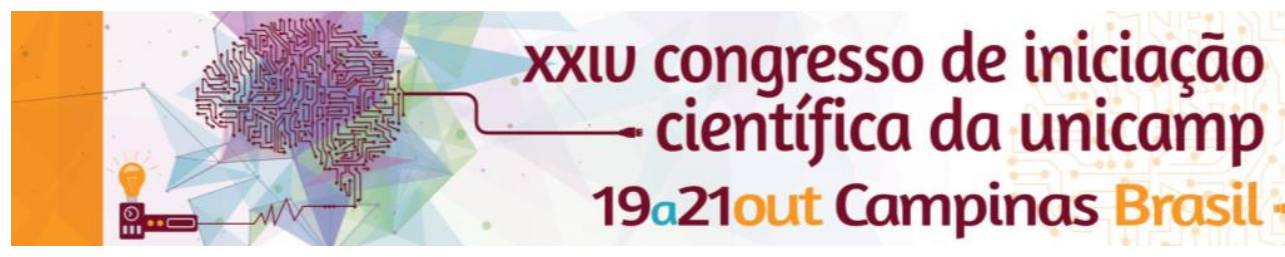

\title{
Animalculo Project - A remote laboratory
}

\section{Gabriela Ferreira de Souza*, Carmen Maria das Graças Grigoletti Mir, Prof. Eduardo Galembeck}

\begin{abstract}
Animalculo Project offers access to a remote laboratory whose main goal is to stimulate children's and adults' interest about science. Through electronic devices as computers, tablets and smartphones, the target audience can access a remote laboratory that explores biodiversity using a microscope and a monitored aquarium.
\end{abstract}

\section{Key words:}

Educational Technology, science education, innovation

\section{Introduction}

In order to attract curiosity in infants and adults and to give them comprehension about the science field ${ }^{1}$, Animalculo project aims to explore the biodiversity through the usage of a microscope and a monitored aquarium. The project was developed to perform online. So using a computer, tablet or smartphone connected to internet, users will be able to follow up the current experiments.

\section{Results and Discussion}

Animalculo Project website was created to host experiments and challenges, whose goals are to develop scientific skills as hypothesis creation and decision making. Beyond that, this website is also a reference source.

\section{Figure 1. Articles for consult}

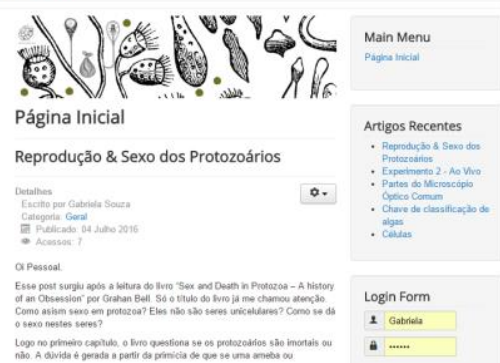

Currently, the experiments on the website are planned to $6^{\text {th }}$ grade students.

Two prototype experiments were executed. For the experiment using the microscope, it was desired the users were capable to identify the materials on the slides. In order to allow the users to see the slides, it was developed a system were the light of the microscope could be turned on and off remotely.

For the aquarium experiment, the prototype was tested. On it, there were two independent tanks whose variables could be changed, as luminosity, temperature, $\mathrm{pH}$ and $\mathrm{O}_{2}$ and $\mathrm{CO}_{2}$ amount could be changed. From it, experiments are being prepared to be available online for teachers and other users (table 1).

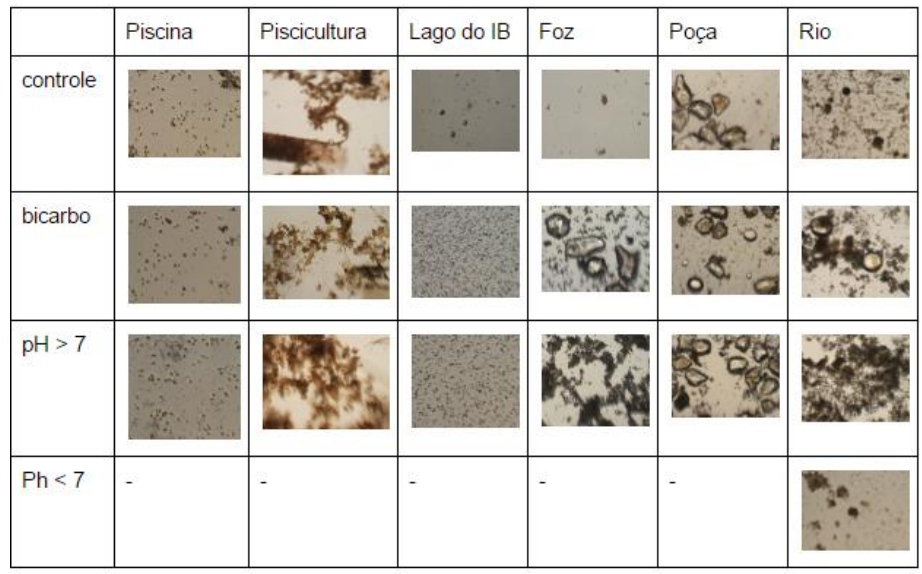

Table 1. Photographs of the results of the model experiment.

On the table above, $\mathrm{pH}$ and $\mathrm{CO}_{2}$ amount over the six samples were changed, attempting to observe the organisms' growth rate under changes in the environment. This first model plays the role to be an orientation about what to expect on the executed experiments.

\section{Conclusions}

The primary results of the project are satisfactory, because it was possible to follow up online the model experiment remotely. Also, all the engines to make these experiment run, worked properly.

\section{Acknowledgement}

We thank Serviço de Apoio ao Estudante (SAE/UNICAMP) department for the scholarship.

\footnotetext{
${ }^{1}$ Pereira dos Santos, Wildson Luiz, Fleury Mortimer, Eduardo, Uma análise de pressupostos teóricos da abordagem C-T-S (Ciência - Tecnologia Sociedade) no contexto da educação brasileiraEnsaio Pesquisa em Educação em Ciências [in line] 2000, 2 (December) : [Date: 9 July 2016] Available in:<http://www.redalyc.org/articulo.oa?id=129518326002> ISSN 1415-2150
} 